\title{
Analysis the Effect of E-Budgeting and Government Internal Control System on the Quality of Financial Reporting of Local Government in Indonesia in Islamic Perspectives
}

\author{
Wahyu Setyawan ${ }^{\mathrm{I}}$, Rindu Rika Gamayuni ${ }^{2}$, Shamsuddeen Muhammad Ahmad ${ }^{3}$ \\ Universitas Lampung ${ }^{1,2}$, Kano State Polytechnic, Nigeria and School of Business Innovation \& \\ Technopreneurship, University Malaysia, Perlis ${ }^{3}$ \\ Wahyusetyawanjogja8@gmail.com ${ }^{I}$ \\ rindu.gamayuni@yahoo.com ${ }^{2}$ \\ shamsudandago@yahoo.com ${ }^{3}$
}

\begin{abstract}
The objective of this study is to determine the impact of e-budgeting and internal government control systems to financial reporting of local governments in Indonesia as measured by the achievement of the unqualified opinion from the report of the Financial Audit Board (LHP BPK) on the Regional Government Financial Reports (LKPD). Financial reporting is a mechanism in the delivery of financial information and a representation of the financial position of transactions carried out by local governments, as an obligation of responsibility for the allocation and use of resources that are useful for accountability and transparency purposes.

The implementation of e-budgeting and the government internal control system in the preparation of financial reporting is a means to realize accountability and transparency in governance in bureaucratic reform. This is consistent with the perspective of Islam providing guidance in the embodiment of the system of good governance government in the form of three pillars, namely transparency, accountability and participation. The study population was all local governments in Indonesia with a sample that local governments in Indonesia are already implementing e-budgeting in the $2017-2018$. This research method is a quantitative empirical research method using secondary data with data analysis performed statistical tests using multiple linear regression with Eviews 9.0.

The results of hypothesis testing and multiple regression analysis with eviews 9.0 show that e-budgeting and government internal control systems are simultaneously influenced positively to financial reporting of local governments in Indonesiain the form of unqualified opinion.
\end{abstract}

Keywords: E-Budgeting, Financial Reporting, Government Internal Control, Islamic Perspective.

Received : November II, 2019 - Revised: November 2I, 2019 - Accepted : December 7, 2019 Universitas Lampung ${ }^{1,2}$, Kano State Polytechnic, Nigeria and School of Business Innovation \& Technopreneurship, University Malaysia, Perlis ${ }^{3}$

E-Mail:wahyusetyawanjogja8@gmail.com ${ }^{1}$.rindu.gamayuni@yahoo.com² ${ }^{2}$

shamsudandago@yahoo.com³ 
Analysis the Effect of E-Budgeting and Government Internal Control System on the Quality of Financial Reporting of Local Government in Indonesia in Islamic Perspectives

Wahyu Setyawan ${ }^{\mathrm{I}}$, Rindu Rika Gamayuni ${ }^{2}$, Shamsuddeen Muhammad Ahmad ${ }^{3}$

\section{A. INTRODUCTION}

Regional autonomy provides opportunities for regional governments to manage resources independently (Undang-Undang No. 23 tahun 2014 tentang Pemerintahan Daerah., n.d.), but it is not balanced with capabilities in terms of financial management in local government including transparency, accountability and public participation in budgeting which become counter productive with the targets in terms of governance and bureaucratic reform. To overcome weaknesses related to aspects of financial management and governance, the central government requires all local governments to implement ebudgeting in the preparation of the budget set out in (Peraturan Pemerintah Nomor 86 tahun 2017 tentang Tata cara Perencanaan, Pengendalian dan Evaluasi Pembangunan Daerah., n.d.). Islam as a value-rich religion provides guidance on the application of a good governance structure in the form of three pillars namely transparency, accountability and participation (Fawaid, 20I0).

Transparency is an institutional transparency in the delivery of information related to public resource management operations to stakeholders (Mardiasmo, 2004). While accountability is fundamentally about the disclosure of public information to parties who have the right to know it (Kholmi, 2013). To realize accountability and transparency requires good financial management and reporting so that information is easy to understand and relevant for stakeholders.

Budget transparency is one form of shidq. Shidq is a liability. Shidq is honesty in receiving, processing, and delivering information. In honesty budget management, it cannot be carried out except with budget transparency. Based on this rule, implementing budget transparency is mandatory. Transparency in this research is accomplished by providing open access to all citizens through e-budgeting. The public must know where the source of funds comes from and what it is used for. With the transparency of the government program budgeting process, the public can know and monitor the progress and success of the government program that has been announced.

The second pillar is accountability. In religious language, this is related to the mandate, faithfulness, and the right promise (al-amanah wa al-wafa 'bi al-'ahdi). The main issue in accounting is regarding accounting accountability. Basically accountability is the essence of Islam. The characteristics of Islamic accountability are derived from the concept of monotheism and the concept of ownership in Islam. Based on these two concepts, a perspective on the implementation of responsibility is revealed, which is elaborated in the aspects of intention, work motivation, and reorientation of work results. Accountability can be defined as an obligation on the part of individuals or bodies entrusted with the management of public resources and those concerned to be able to respond to matters of responsibility. These values can be understood as an 
awareness of human nature as khalifatullah fil ardh and the relationship of accountability between human beings (habluminannas).

Accountability is manifested in the quality of financial reporting which reflects that Government Financial Reports has been fairly presented in relation to all material matters. Government Financial Reports who obtain unqualified opinion have much better accountability. Where the Government Financial Reports that obtains the unqualified opinion, the financial statements shall be in compliance with the accounting standards of the Government which are presented and disclosed appropriately and are free of all material things, the effectiveness of the government internal control system is good and there are no findings of non-compliance with statutory regulations, So that the information on the financial statement can be useful for users. The qualitative characteristics of the financial statements of local governments, which are requirements as set out in the Conceptual framework for government accounting (Government Regulation No. 7I, 20I0), are relevant, consisting of feedback value, forecast value, complete and timely. Reliable consists of verifiable, honest and neutral presentation. It can be understood and can be compared.

The third pillar is participation. In Islamic view, budget participation is written in the verses of the Koran, namely syura. From the basic value of this syura, a legal principle regarding the budgeting process can be derived from the principle of community participation. Participation meant here is community togetherness to collaborate in discussing, planning, and making public resource management policies as well as overseeing and evaluating their implementation. This terminology in religious language is known as the principle of at-ta'awun (mutual cooperation). This pillar is important because no matter how many individuals have held the character of honesty, responsibility, and fairness, but without coupled with a spirit of cooperation, it is difficult to reach the common good. In the e-budgeting mechanism there are stages of the deliberation planning (Musrenbang) which involves every level of the region from the village to the province for the preparation of program activities and budget allocations. The e-budgeting process encourages the public to participate and deliberate in submitting proposed programs and activities that will be included in the work plan of the local government (RKPD) to then be conveyed to the legislature to be discussed with the executive into the Policy of General Budget and Priority of Budget (KUAPPAS). The results of the Policy of General Budget and Priority of Budget (KUAPPAS) document will later be used as the basis for preparing a Budget Work Plan (RKA) and eventually becoming a Budget Implementation Document (DPA). 
Analysis the Effect of E-Budgeting and Government Internal Control System on the Quality of Financial Reporting of Local Government in Indonesia in Islamic Perspectives

Wahyu Setyawan ${ }^{1}$, Rindu Rika Gamayuni ${ }^{2}$, Shamsuddeen Muhammad Ahmad ${ }^{3}$

\section{B. THEORITICAL}

E-budgeting is an information system for regional financial management that is integrated by using a web-based computer application program starting from the planning stage, Preparation of the budget on the basis of applicable regulations, that aims to improve the quality of spending, accountability and transparency of regional financial management. E-budgeting in budgeting guarantees consistency, accountability and transparency between program planning and activities towards its budget. All budgeting procedures through e-budgeting are done online and will be well documented through digital footprints and all stakeholders can oversee public funds so as to increase accountability and minimize misuse of public funds. The stages of e-budgeting according to (Peraturan Pemerintah Nomor 86 tahun 2017 tentang Tata cara Perencanaan, Pengendalian dan Evaluasi Pembangunan Daerah., n.d.) consist of Local Government Work Plans (RKPD), Policy of General Budget and Priority of Budget (KUA-PPAS), Budget Work Plans (RKA) and Budget Implementation Documents (DPA).

Government Internal Control System (SPIP) according to (Peraturan Pemerintah Nomor 60 tahun 2008 tentang Sistem Pengendalian Intern Pemerintah., n.d.) is a system and procedure for evaluating internal control effectiveness of local governments to ensure that objectives are met through effective and efficient operations, reliability of financial statement, the secure of government assets, and Compliance with the laws and regulations. SPIP consists of five elements, In particular environment of control, assessment of the risk, control of activities, communications and information and monitoring of controls.

The Committee of Sponsoring Organizations of Tread way Commission (COSO, 2013) Defines internal control as follows: ' Internal control is a system carried out by an entity's board of directors, management and other staff, intended to provide reasonable assurance on the achievement of goals relating to activities, reporting and compliance.

In relation to the effectiveness preparation of the financial statements, the merits of implementing an internal control system can affect the quality of local government financial reports. Internal control within the scope of local government is designed compliance with (Peraturan Pemerintah Nomor 60 tahun 2008 tentang Sistem Pengendalian Intern Pemerintah., n.d.) which becomes a criterion for giving opinion through an evaluation of the effectiveness of the SPI. Arens (Arens, A. A., Elder, R. J., dan Beasley, 20II) mentions that internal control is created to provide adequate confidence to achieve the objectives, adequacy and effectiveness of the operational handle, reliability of financial statement and compliance accordance to laws and regulations. 
The Quality of Local Government Financial Reporting is all aspects related to the process of providing and delivering financial information for interested parties (stakeholders). These aspects include the institutions involved (legislative and executive), the applicable regulations including government accounting standards, and the mechanism for delivering information in the context of the financial transparency. Government financial statements are a medium in the delivery of financial information and representation of the financial performance of transactions made by the government. Local government financial reporting must have some qualitative characteristics that are required to obtain unqualified opinion from Financial Audit Board (BPK).

The qualitative characteristics of the financial statements of local governments, which are requirements as set out in the Conceptual framework for government accounting (Government Regulation No. 7I, 2010) consist of feedback value, prediction value, complete and timely. Reliable consists of verifiable, honest and neutral presentation. It can be understood and can be compared.

From some of the explanations above, the research model can be described as follows:

Figure I

Research Framework

Implementation of e-budgeting

Government Internal Control

System (SPIP)

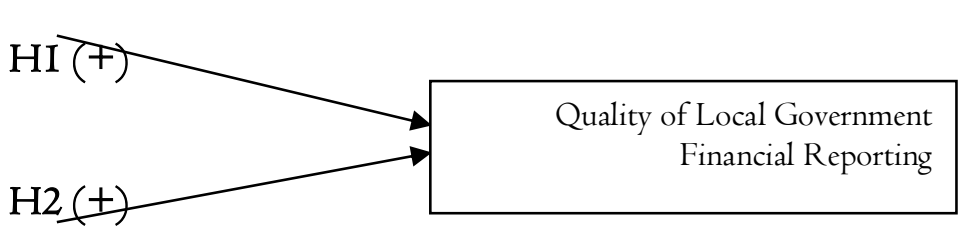

\section{The Effect of E-Budgeting Implementation on the Quality of Local Government Financial Reporting.}

The e-budgeting system which consists of Regional Government Work Plans (RKPD) whose output is in the form of a Policy of General Budget and Priority of Budget (KUA-PPAS), which in its preparation involves all parties will be able to increase transparency, accountability and suitability between planning documents, budget preparation and realization in government financial reports. Reporting reflects the financial activities of the local government which showed compliance with the implementation of the regional budget. The increasing volume and complexity of government financial transactions must be balanced by increasing the ability of regional financial management so that the quality of local government financial reporting is 
Analysis the Effect of E-Budgeting and Government Internal Control System on the Quality of Financial Reporting of Local Government in Indonesia in Islamic Perspectives

Wahyu Setyawan ${ }^{1}$, Rindu Rika Gamayuni ${ }^{2}$, Shamsuddeen Muhammad Ahmad ${ }^{3}$

better. The budgeting process with the e-budgeting systemic done automatically and no longer manually so that it can avoid errors in government financial reports data, maintain program and budget consistency and timeliness in preparing government financial reports. All of the above will have an impact on the quality of government financial reporting from the aspect of the relevance and reliability of government financial information.

(RitchiHamzah, 20I5) found that there was a positive significant effectof ebudgeting features on the quality of accounting information systems and local government financial reporting. The features as well as the ease and usefulness of ebudgeting can increase the intensity of the use of the system better by its users so that the accounting information generated is also more accurate, relevant and transparent. The results of another research conducted by (Srivastava, 20II) found that the implementation of e-budgeting both in terms of government policy, public service administration, plan reports and budget realization had a positive effect on the level of quality of financial information produced by the government so that it had an impact on increasing public confidence in terms of transparency the budget. The quality of the accounting information system will produce good accounting information, which is the information data generated is relevant, reliable and accurate for the decision making process.

\section{HI: The implementation of e-budgeting has a positive effect on the quality of local government financial reporting}

\section{The Effect of Government Internal Control System on the Quality of Local Government Financial Reporting.}

The higher the level of SPIP, the better quality of the organization's internal control system and the better the quality of its financial reporting, and conversely the lower the SPIP level, the lower the quality of the organization's internal control system and the lower of the quality of financial reporting. The Audit Opinions are related to the many findings of internal control weaknesses in regional government in the form of standard operation procedure that have not been carried out optimally, segregation of duties, authorization and documentation functions and recording of assets that have not fulfilled aspects of examining government financial reporting opinion, namely the effectiveness of internal control structures that affect BPK's opinion on government financial reporting.

According to (Mardiasmo, 2004) in (Widyaningsih, 20I I) that weak internal control in the form of a poor accounting system and procedure will make financial reports to be unreliable and relevant for economic decision making. (Indriasari, D. \& Nahartyo, 
2008) found that the internal control structure of local government has a beneficial effect on the quality of local government financial reporting because if the Program of internal control runs according to all stages, matters related to the standard operating procedures for supervision, authorization procedures, recording procedures, procedures for segregation of duties and documentation will run well.

Previous research conducted by (Indriasari, D. \& Nahartyo, 2008) empirically proved that local government internal control systems have a positive effect on the quality of local government financial reporting in terms of achieving effectiveness and efficiency operations, compliance with the laws and regulations and the reliability of the presentation of government financial statements.

$\mathrm{H} 2$ : The Government's Internal Control System has a positive effect on the quality of local government financial reporting

\section{METHODOLOGY}

\section{Population and Research Samples}

The population of this study is all local governments in Indonesia. The sampling method with purposive sampling is that local governments in Indonesia that have implemented e-budgeting in 2017-2018 are 218 local governments.

This study uses secondary data in the form of Audit Reports (LHP) of BPK RI on the opinion of the Government Financial Report (LKPD) and the Government Internal Control System (SPIP).

The dependent variable in this research is the quality of financial reporting by local government as measured by the achievement of unqualified opinion from financial Audit Board (BPK).

The independent variable in this study is an e-budgeting. The implementation of e-budgeting is measured by the level of implementation and integration of the local government planning and budgeting system using scoring I to 5 .

Table I

\begin{tabular}{|l|c|}
\hline \multicolumn{1}{|c|}{ Category } & Scoring \\
\hline \hline Not yet implemented e-planning and e-budgeting & I \\
\hline Implementation of e-planning for 5 years (RPJMD and Strategic Plan) & 2 \\
\hline $\begin{array}{l}\text { Implementation of e-planning for 5 years and annually (RPJMD, Renstra, Musrenbang, } \\
\text { RKPD, Renja) }\end{array}$ & 3 \\
\hline $\begin{array}{l}\text { Integration of e-planning, e-budgeting systems (RPJMD, Strategic Plan, ASB \& SSH, } \\
\text { Musrenbang, RKPD, Renja, KUA PPAS) }\end{array}$ & 4 \\
\hline $\begin{array}{l}\text { Integration of e-planning, e-budgeting systems with local financial management (Full } \\
\text { Implementation) (RPJMD, Renstra, ASB \& SSH, Musrenbang, RKPD, Renja, KUA PPAS, } \\
\text { Budgeting Application, Financial Administration and Reporting) }\end{array}$ & 5 \\
\hline
\end{tabular}

Source: Permendagri No. 86 year 2017 
Analysis the Effect of E-Budgeting and Government Internal Control System on the Quality of Financial Reporting of Local Government in Indonesia in Islamic Perspectives

Wahyu Setyawan ${ }^{1}$, Rindu Rika Gamayuni ${ }^{2}$, Shamsuddeen Muhammad Ahmad ${ }^{3}$

\section{Government Internal Control System (SPIP).}

This variable is measured using the SPIP maturity score obtained from the Quality Assurance results by the State Finance and Development Controller (BPKP).

Table 2

\begin{tabular}{|l|c|}
\hline SPIP MATURITY & Scoring \\
\hline Not Available & Less than I.0 $(0<$ Score $<$ I.0 $)$ \\
\hline Stub & I.0 to less than $2.0($ I.0 $<$ score $<2.0)$ \\
\hline Developing & 2.0 to less than $3.0(2.0<$ score $<3.0)$ \\
\hline Defined & 3.0 to less $4.0(3.0<$ score $<4.0)$ \\
\hline Managed and Measured & 4.0 to 4.4 less $(4.0<$ score $<4.5)$ \\
\hline Optimum & Between 4.5 to $5.0(4.5<$ score $<5)$ \\
\hline
\end{tabular}

Source: BPKP Regulation No.4 year 2016

The method of data analysis is done by statistical tests using multiple linear regression with the following equation.

\section{Quality of Financial Reporting $=\alpha+\beta$ I e-budgeting $+\beta 2$ SPIP $+€$}

Information :

Quality of Financial Reporting : Unqualified Opinion

$\alpha$

e-budgeting

SPIP

$€$

: Konstanta

: Implementation score of e-budgeting

: Internal Control System Maturity Score

:Error Term

\section{RESULTS AND DISCUSSION}

Table 3

Descriptive Statistics

\begin{tabular}{|l|c|c|c|}
\hline & Y & XI & X2 \\
\hline Mean & 4.862385 & $3.44954 \mathrm{I}$ & 2.759174 \\
\hline Median & 5.000000 & 3.000000 & 3.050000 \\
\hline Maximum & 5.000000 & 5.000000 & 3.880000 \\
\hline Minimum & $\mathrm{I} .000000$ & 3.000000 & $\mathrm{I} .010000$ \\
\hline Std. Dev. & 0.542530 & $0.6366 \mathrm{I} 3$ & 0.698498 \\
\hline
\end{tabular}

Source: Data processed with eviews 9, 2019 
Descriptive statistics results above table shows the number of observations in the study amounted to 218 data of local governments with a span of time during 2017-2018. The results of the descriptive statistical analysis of each variable are as follows:

a. The highest $(\mathrm{Y})$ opinion is 5.00 million and the lowest is 1.000000 . The mean and median values of BPK's opinions are 4.862385 and 5.000000. The standard deviation of BPK's opinion is 0.542530 . The mean value of the BPK's opinion is greater than the standard deviation value, so it can be concluded that the average of all data on the opinion variable is able to describe the data of all the variables well.

b. The implementation of e-budgeting (XI) is highest at 5.00 million and the lowest is at 3 million. The mean and median values of e-budgeting are 3.44954I and 3.000000. The standard deviation of e-budgeting is 0.636613 . The mean value of the e-budgeting application is greater than the standard deviation value, so it can be concluded that the average of all data on the e-budgeting application variable is able to describe the data of all the variables well.

c. Government internal control system (X2) the highest of 3.880000 and the lowest of I.0I0000. The mean and median values of X2 are 2.759174 and 3.050000. Standard deviation of the X2 is 0.698498 . The mean Of X2 is higher than the standard deviation values, so it can be concluded that the average of all data on the $\mathrm{X} 2$ variables is able to describe the data of all variables well

\section{Panel Data Regression Analysis}

After selecting the model using the Chow and Hausman test, the research model used by the author is panel data with a fixed effect (FEM) model with the following estimation result :

\section{Tabel 4}

\begin{tabular}{|c|c|c|c|c|}
\hline & $\begin{array}{r}\text { } \\
\text { Metho } \\
\text { Date: II } \\
\text { Cross- } \\
\text { Total }\end{array}$ & $\begin{array}{l}\text { Variable: Y } \\
\text { ast Squares } \\
\text { ime: I2:00 } \\
\text { 2017 2018 } \\
\text { included: } 2 \\
\text {-luded: } 109 \\
\text { nced) obser }\end{array}$ & ations: 218 & \\
\hline Variable & Coefficient & Std. Error & $\mathrm{t}$-Statistic & Prob. \\
\hline $\mathrm{C}$ & 3.501070 & 0.317746 & I I.0I844 & 0.0000 \\
\hline XI & 0.259860 & 0.065009 & 3.997275 & 0.0001 \\
\hline $\mathrm{X} 2$ & 0.168499 & 0.070370 & 2.394465 & 0.0184 \\
\hline
\end{tabular}

https://ejournal.radenintan.ac.id/index.php/ikonomika 
Analysis the Effect of E-Budgeting and Government Internal Control System on the Quality of Financial Reporting of Local Government in Indonesia in Islamic Perspectives

Wahyu Setyawan ${ }^{1}$, Rindu Rika Gamayuni ${ }^{2}$, Shamsuddeen Muhammad Ahmad ${ }^{3}$

\begin{tabular}{|rrrr|}
\multicolumn{4}{|c|}{ Effects Specification } \\
\hline \hline \multicolumn{4}{c|}{ Cross-section fixed (dummy variables) } \\
\hline \hline R-squared & 0.708458 & Mean dependent var & 4.862385 \\
Adjusted R-squared & 0.408742 & S.D. dependent var & 0.542530 \\
S.E. of regression & 0.417169 & Akaike info criterion & 1.396034 \\
Sum squared resid & 18.62125 & Schwarz criterion & 3.119332 \\
Log likelihood & -41.16772 & Hannan-Quinn criter. & 2.092099 \\
F-statistic & 2.363762 & Durbin-Watson stat & 3.963636 \\
Prob(F-statistic) & 0.000006 & & \\
\hline \hline
\end{tabular}

Source: Data processed with eviews 9, 2019

Based on the regression results above, the equation model using the fixed effect method can be formulated as follows :

$$
\begin{array}{ll}
Y & =\alpha_{0}+\beta_{1} X 1_{i t}+\beta_{2} X 2_{i t}+u_{i t} \\
\mathrm{Y} & =3.501070+0.259860+0.168499
\end{array}
$$

The above equation can be explained that:

a. Constants a of 3,501070, meaning that if the application of e-budgeting and internal control systems of local governments is 0 , then the BPK's opinion is 3.501070.

b. The coefficient value of the variable implementation of e-budgeting (XI) is 0.259860 shows a positive sign. This means that if the independent variable adopts e-budgeting increases by $\mathrm{I} \%$, then $\mathrm{Y}$ variable will increase by $25.99 \%$.

c. The coefficient value of the X2 variable is 0.168499 shows a positive sign. This means that if the independent variable of the internal control system of the local government increases by I\%, then the $\mathrm{Y}$ variable will increase by $\mathrm{I} 6.85 \%$.

\section{Hypothesis testing}

Coefficient of Determination $\left(\mathrm{R}^{2}\right)$

The coefficient of determination $\left(\mathrm{R}^{2}\right)$ aims to see how much the ability of the independent variable to explain the dependent variable seen through adjusted $\mathrm{R}^{2}$. The results can be seen in the table below:

\section{Tabel 5}

Coefficient of Determination $\left(\mathrm{R}^{2}\right)$

R-Square Adjusted-R Square

$0.708458 \quad 0.408742$

Source: Data processed with eviews 9, 2019 
Accordance to the result above, The coefficient of determination $\left(\mathrm{R}^{2}\right)$ in the regression in the fixed effect model is 0.708458 , Showing that the proportion of the influence of the e-budgeting (XI) and the government internal control system (X2) of the quality of financial statement of local government $(\mathrm{Y})$ is $70.85 \%$, while the remaining $29.15 \%(100 \%-70.85 \%)$ is influenced by other variables that are not in the regression model.

\section{Partial Testing (t-stat)}

The test was used to determine whether the independent variable implementation of e-budgeting and internal control systems of local governments partially influential and significant to the BPK opinion variable. Criteria for testing carried out are:

a. If the value of prob $\leq \alpha(0.05)$, then $\mathrm{Ho}$ is rejected and $\mathrm{Ha}$ is accepted This means that there is a significant effect of the independent variable on the dependent variable.

b. If the value of prob $\geq \alpha(0.05)$, then Ho is accepted and $\mathrm{Ha}$ is rejected This means that there is no significant effect between independent variable against dependent variable.

The results can be seen in the table below:

\section{Tabel 6}

\section{T-Statistic Testing Result}

\begin{tabular}{|c|c|cc|c|}
\hline Variabel & prob & $\mathrm{H}_{a}$ & Alpha & Result \\
\hline XI & 0,000I & Accepted & 0,05 & Significant \\
\hline X2 & 0,0I84 & Accepted & 0,05 & Significant \\
\hline \multicolumn{7}{|c|}{ Source: Data processed with eviews 9, 20I9 } \\
\hline
\end{tabular}

Based on the table above, then:

\section{a. $\mathrm{HI}=$ The implementation of E-budgeting has a positive effect on the quality of financial reporting of local governments in Indonesia}

The probability value of the e-budgeting implementation variable shows the prob value $>$ alpha level value $(\alpha=5 \%)$ of $0.000 \mathrm{I}<0.05$, so the e-budgeting implementation variable has a significant effect on BPK's opinion. The conclusion of the research accepting HI means that the application of e-budgeting (XI) has a positive effect on the quality of financial reporting of local governments in Indonesia. E-budgeting is able to reduce information asymmetry between the government and the public regarding the use of budgets and the allocation of public resources. The participation and transparency in 
Analysis the Effect of E-Budgeting and Government Internal Control System on the Quality of Financial Reporting of Local Government in Indonesia in Islamic Perspectives

Wahyu Setyawan ${ }^{1}$, Rindu Rika Gamayuni ${ }^{2}$, Shamsuddeen Muhammad Ahmad ${ }^{3}$

the budget process by e-budgeting provides more relevant and reliable financial information as a basis for the preparation of LKPD. These results confirm the results of previous studies conducted by (RitchiHamzah, 2015) conducted a study where the results of the study showed that there was a significant positive influence between the use of e-budgeting on the quality of accounting information systems and local government financial reporting.

\section{b. H2 = Government Internal Control System has a positive effect on the quality of financial reporting of local governments in Indonesia}

The probability value of the government internal control shows the probability value $<$ significant level of negligee $(\alpha=5 \%)$ of $0.0184<0.05$, so that the variable of the government internal control has a significant effect on BPK's opinion. The conclusion of the study accepting $\mathrm{H} 2$ means that the government internal control system has a significant positive effect on the quality of financial reporting of local governments in Indonesia.

The internal control system is able to guarantee the reliability of local government financial reporting through a series of SOP implementations, a tiered authorization process, segregation of duties as well as documentation and recording. SPIP assists the government in carrying out control and evaluation of the responsibility for using and reporting financial resources mandated to it. The better SPIP is going to be able to minimize the discovery of weaknesses in the system of internal control which means the better structure of the internal controlsystem. The better internal control structure, the better the quality of financial reporting in LKPD. These results confirm the previous research by (Indriasari, D. \& Nahartyo, 2008), which empirically proved that the local government internal control system has a positive effect on the quality of local government financial reporting because if the internal control system runs according to all levels, matters relating to the standard operating procedures for supervision, authorization procedures, recording procedures, procedures for segregation of duties and documentation will run well.

\section{Test F Statistics}

$\mathrm{F}$ test results in this study can be seen in the following table:

Tabel 7

F Statistic Testing Result

\begin{tabular}{|l|c|c|c|}
\hline F-Statistik & prob & Alpha & Result \\
\hline 2.363762 & 0.000006 & 0,05 & Significant \\
\hline
\end{tabular}


Based on the table above, the F-statistic probability value is smaller than alpha $(0.05)$, that is $0.000006<0.05$, which means that e-budgeting and government internal control simultaneously has a significant effect on financial statement of local government. The conclusion of this research is accepting $\mathrm{Ha}$, namely the implementation of e-budgeting and the government internal control simultaneously have a significant effect on the quality of financial reporting in the form of BPK's opinion.

\section{E. CONCLUSION}

Accordance to the results above, it may be concluded as follows:

The implementation of e-budgeting has a significant positive effect on the quality of local government financial reporting where the better the level of implementation of e-budgeting systems in local governments at the RKPD, KUA-PPAS stages, the quality of local government financial reporting as measured by the opinion given by the BPK will be increasingly well. A unqualified opinion (WTP) illustrates the consistency between the program and its budget realization because in the preparation and realization of the budget there is public participation and public transparency so as to produce accountability in the form of financial reports that are more relevant and reliable for the decision making process.

Government Internal Control System has a significant positive effect on the quality of local government financial reporting where the better the effectiveness score of the Government Internal Control System on local governments, the quality of local government financial reporting as measured by the opinion given by the BPK will be better. This illustrates that the Standards and procedures have been carried out optimally and the LKPD opinion audit aspects are met, namely from the aspects of conformance to SAP, the adequacy of disclosure and compliance with laws and regulations. In addition, all matters related to the standard operating procedures for supervision, authorization procedures, recording procedures, procedures for segregation of duties and documentation will run well.

Financial reporting in the form of accounting information in an Islamic perspective is closely related to aspects of accountability and transparency. Accountability can be defined as an obligation on the part of individuals or authorities entrusted with the management of public resources and those concerned to be able to respond to matters of responsibility. This relates to mandate, faithfulness, and the right promise (al-amanah wa al-wafa 'bi al-'ahdi). These values can be understood as an awareness of human nature as khalifatullah fil ardh and the relationship of accountability between fellow and human beings (habluminannas). 
Analysis the Effect of E-Budgeting and Government Internal Control System on the Quality of Financial Reporting of Local Government in Indonesia in Islamic Perspectives

Wahyu Setyawan ${ }^{1}$, Rindu Rika Gamayuni ${ }^{2}$, Shamsuddeen Muhammad Ahmad ${ }^{3}$

\section{REFERENCES}

Arens, A. A., Elder, R. J., dan Beasley, M. S. (20II). Auditing dan Jasa Assurance, Pendekatan Terintegrasi. Jakarta: Erlangga.

Fawaid, A. (2010). Islam, Budaya Korupsi dan Good Governance. Jurnal Online.

Http://Karsa.Stainpamekasan.Ac.Id/Index.Php/Jks/Article/Download/45/36,D iaksestanggal 08 November 2019.

Indriasari, D. \& Nahartyo, E. (2008). Pengaruh Kapasitas Sumber Daya Manusia,

Pemanfaatan Teknologi Informasi dan Pengendalian Intern Akuntansi Terhadap

Nilai Informasi Pelaporan Keuangan Pemerintah Daerah (Studi pada Pemerintah

Kota Palembang dan Kabupaten Ogan Illir)”. Kumpulan Simposium Nasional

Akuntansi XI Di Pontianak, 23-24 Juli.

Kholmi, M. (2013). Persepsi pengurus partai terhadap akuntabilitas keuangan partai politik. Jurnal Reviu Akuntansi Dan Keuangan ISSN: 2088-0685 Vol.3, No. I, 364-365.

Mardiasmo. (2004). Perwujudan Transparansi dan Akuntabilitas Publik Melalui Akuntansi Sektor Publik: Suatu Sarana Good Governance. Jurnal Akuntansi Pemerintah 2(I):I-I7.

Peraturan Pemerintah Nomor 60 tahun 2008 tentang Sistem Pengendalian Intern Pemerintah. (n.d.).

Peraturan Pemerintah Nomor 86 tahun 2017 tentang Tata cara Perencanaan,

Pengendalian dan Evaluasi Pembangunan Daerah. (n.d.).

RitchiHamzah, I. W. \& A. S. (2015). Research Program On Key Success Factors of egovernment and their impact on accounting information quality. 2nd Global Conference On Business and Social Sciences 673-680.

Srivastava, S. C. (20I I). Is e-government providing the promised returns?", Transforming Government: People, Process and Policy, Vol. 5 ISS 2 pp. IOTII3.

Undang-Undang No. 23 tahun 2014 tentang Pemerintahan Daerah. (n.d.). Widyaningsih, A. (20II). Hubungan efektifitas sistem akuntansi keuangan daerah dan pengendalian intern dengan kualitas akuntabilitas keuangan: Kualitas informasi laporan keuangan sebagai variabel intervening. Simposiun Nasional Akuntansi XIV. Aceh Vol I4 No I. 